\title{
THE CREATIVE SUBURB: A STUDY IN CREATIVE REFLECTIVE PRACTICE
}

\author{
MALCOLM HOLZ \\ Queensland University of Technology, HOLZink, Australia.
}

\begin{abstract}
As long as population growth continues, policies for urban consolidation closer to city centres fail, and there is land available, Australians will continue to build in new Greenfield suburbs. However, the 50-year legacy of the homogeneous one-size-fits-all approach to suburbia beyond the sticks and sometimes hours away from where one can find a job, is proving unsustainable, the commute alone a significant contributor to greenhouse gas emissions across the globe. The 'creative suburb' was inspired by the possibility to create new, innovative and entrepreneurial suburbs, places which are more selfsufficient and self-contained than the 'product' perpetuated down under even today. The 'creative suburb' draws on significant primary research with suburban home-based creative industries workers, vernacular architecture, and town planning in the Toowoomba region, in the state of Queensland, Australia, as inspiration for a series of new building and urban designs available for innovators operating in new suburban greenfield situations in Queensland and possibly further a field. This paper considers the role 'creative reflective practice' played in the process of developing the building and urban designs presented in a book and showcased in a building as creative outputs of this practice-led and property development industry embedded inquiry.

Keywords: creative reflective practice, reflective practice, reflective research, creative suburb, vernacular research, vernacular creativity, vernacular architecture, creative city
\end{abstract}

\section{INTRODUCTION}

Reflective practice is becoming synonymous with contemporary research practice [1]. 'Critical' reflective practice [2] is notably nascent in creative industries, engaging in the related areas of 'practice-led' or 'practice-based', 'action' [3,4] and 'performative' research [5].

The creative suburb: building and urban designs for suburban innovators is typical of these emergent research innovations. The creative suburb includes a book, a building, and an exegesis.

The book and building are 'creative' outputs; the exegesis, the 'critical' output [3]. All three products of the creative suburb research project outputs 'speak' to each other, although different 'voices' are used in each. As a creative output, designed to attract a market, the book is aspirational, conversational, and for those interested, technical. The building, that is, construction of a 1:1 scale model of one of the designs featured in the book, is aligned with the processes of trialling and prototyping common in applied commercial research [5]. The exegesis frames both the book and building and includes reflection and contextualisation of the project in terms of how research aims and objectives were achieved and the methodological approach undertaken.

The final 'thesis' is the combination of the three outputs into one package; in essence an expression, on the one hand, of a breakdown of the historic binary split between practice and theory, and, on the other, to celebrate a burgeoning blend of creativity and criticality in research practice underpinned and informed by reflection. 'Creative reflective practice' defines the approach prevalent in the creative suburb research. 


\section{THE CREATIVE SUBURB RESEARCH}

The creative suburb research is a practice-led, action research project, which responds to the circumstance that despite attempts by some progressive local governments and housing and property developers to introduce a mix and variety of well-designed housing and land uses, Australian suburbia still comprises homogeneous tracts of large detached houses on large lots, home to workers in commercial, retail, and industrial areas often many kilometres away. As in other western countries, this situation is hardly sustainable.

In economic terms alone, the spectre of repossession from failure to meet housing mortgage repayments struck hard during and after the global financial crisis 2008/2009 as a result of 'sub-prime' (undesirable) lending on repetitively large houses (so-called 'McMansions') in the United States. In western nations where home ownership accounts for a large proportion of residents' wealth, the talk around the dinner and coffee table is no longer how big one's house is, rather how small one's debt is. The monetary, as well as social and environmental costs of living in the suburbs - including having to drive to and from work, shops, and services somewhere else - are now being carefully reconsidered.

The 'creative class' Florida [6] has known of the benefits of living in or close to a major centre in the city for as long as the suburbs have been set on; the search for cheaper living and working conditions, close to cafés, culture, and other creative people, is what drove artists and writers of the Beat Generation (such as Allen Ginsberg) to move into disused warehouses in San Francisco during the 1950s. It is what similar creative industry workers (CIWs) continue to do in living and working in inner-city locations such as The Valley and West End in Brisbane, Queensland today.

Florida [6], for example, confirmed the 'creative class' preference to live and work in funky, diverse, inner-city areas. Landry [7] expanded Florida's [6] original notion into a citycentric policy-orientated toolkit for urban innovators. Evans [8] outlined rationales for cultural and creative industry 'quarters', ostensibly in the city. Evans argues that these creative clusters are a key contributor to a knowledge-based (creative) economy.

For CIWs involved in the interlocking and often interdependent fields of art, film, and interactive gaming, or providing business-to-business services in areas such as architecture, advertising and marketing, design, as well as web, multimedia, and software development [9], the inner city is an obvious choice. But what if you happen to be an artist or designer (part of the 'super-creative core' identified by Florida [6] who cannot find an affordable place in the highly sought after city centre, a location attractive to management or legal experts (the 'creative professionals' identified by Florida [6]) who may have driven the price of purchase or renting a place out of reach of even the most commercially successful of the super creative core? What if you happen to be a CIW who does not like the frenetic energy of city centres, what if your work relies on a brief or commission which can be received and worked on remotely, or what if you prefer a suburban home-based situation to fulfil what may be simply a personal desire for artistic exploration?

The ideal of a more self-contained, self-sufficient, and sustainable suburbia spawned this research: to consider the potential for a greater diversity of typically smaller and more affordable houses, home-based business, and mixed-use centres to contribute to a suburbia in which CIWs may be attracted to live and work. A principal task of the creative suburb research was to determine what conditions would suit CIWs if they were to be enticed to live and work in the suburbs. Was it in complete contradiction to 1950-1970s Heidegger that the dwelling house and work place may no longer be 'here' and 'there', but rather, potentially and poetically, coincident, in the suburbs, where typically (paraphrasing Heidegger [10]) 'houses' 
might still be the cheapest, well planned, easy to keep, open to air, light, and sun, but, almost inevitably, are not designed to facilitate home-based business nor creative industries?

Felton and Collis [11] identified two distinct categories of CIW; 'commercial creatives' those people who either worked in, and/or ran a small-to-medium commercial enterprise (SME) - or 'artisans' - those involved in generally individual creative endeavours such as visual art, music or writing' [11].

The artisans of creative suburbia research relate closely to the characteristics of CIWs identified in substantive studies into a 'vernacular creativity' [12], which argued for a rethinking of what constitutes creativity and advocated the need to consider the often marginal and everyday spaces in which creative industries work takes place. Both the creative suburbia and vernacular creativity research strongly suggests that there is a suburban spread (of creative industries work and workers), and not the stupid suburban sprawl so criticised by the new urbanists [13].

\section{THE HOME WORKHOUSE}

The concept of a 'home workhouse' was developed to focus the research. The home workhouse has its origins in the traditional 'shop top house' intact remnants of which are found in the towns and suburbs in Queensland including 'The Old Bakery', Eumundi on Queensland's Sunshine Coast and in Brisbane, 48 Enoggera Terrace, Red Hill (Figs 1 and 2).

A home workhouse is fundamentally a small-scale mixed use building, which are otherwise known these days as 'live-work dwellings' eloquently described by Duany et al. [13] in the 'Smart Growth Manual', and also the focus of Dolan [14] who asserted that live-work buildings could result in a 'zero commute'.

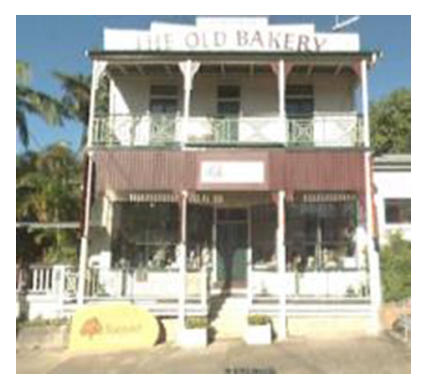

Figure 1: 'The Old Bakery’ Eumundi, Queensland.

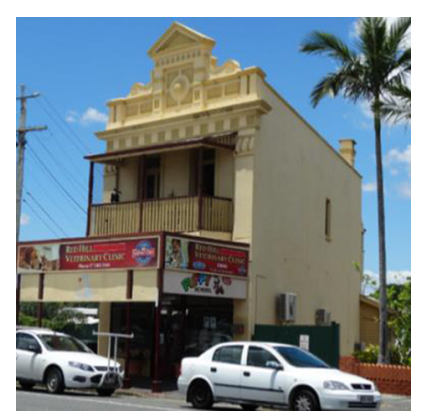

Figure 2: 48 Enoggera Terrace, Red Hill, Brisbane. 
A home workhouse also encompasses a contemporary variant of the shop top house, the 'Soho', a small office home office or the classic mixed use buildings coming from 'south of Houston Street' in New York. A homework house also embraces Holliss' [15] definition of a 'workhome' - the basis of an urban design revolution - in that 'home is where the work is'.

A home workhouse accommodates 'home-based business' as defined in related Queensland statutory planning instruments (DSDIP [16] and Sustainable Planning Act (SPA) [17]) and may also be defined as a 'mixed use development' albeit of a micro-small scale in terms of both the building and commercial scale of operation.

To create the building and urban designs, the creative suburb study sampled CIWs building on Australian Research Council (ARC) funded Queensland University of Technology (QUT) research into 'creative suburbia', which demonstrated on the one hand that not all of the 'creative class' [6] are choosing the city centre in which to live and work, and on the other, that the suburbs are not entirely full of desperate housewives. The creative suburbia research showed that CIWs are finding a 'live-work' situation in existing, often old suburbs in houses never designed or built for the purpose. The creative suburb research asked whether there could be an opportunity for CIWs to find a 'home workhouse' suited to their dreams, aspirations, wants, and needs ('dawning') in newly developing suburbs.

The creative suburb research checked in on the creative suburbia research through a series of interviews of CIWs and developers of home-based business and micro-small mixed use in Queensland. The building designs were additionally informed through a succession of workshops.

The urban designs were developed using both the emergent building designs and industry best practice in Queensland, including the progressive provisions of the Toowoomba Regional Planning Scheme (TRC planning scheme). The current TRC planning scheme came into effect on 1 July 2012. It is the first scheme to be introduced and gazetted under the Queensland SPA 2009 [17] and includes unprecedented planning provisions designed to facilitate development of a greater diversity of more affordable housing and home-based business in the region (including the house on top of the shop), rather than impede their development, the latter the case historically in Queensland and in particular in Toowoomba.

The recency of the TRC planning scheme means that the development industry has not had the opportunity to fully deliver on its promising provisions; built examples for lived experience and/or evaluation are not yet available. It is also highly unlikely that the community and/or customers considering an investment are aware of the 'live-work' and/or home-based business opportunities that may be available under the scheme. New designs and interventions are required to demonstrate these opportunities. A key aim of the creative suburb research was therefore to present and demonstrate ideas that may be taken up by the planning, design, and development industries and help deliver more mixed use neighbourhoods and a more creative suburbia at least in the Toowoomba region. A 'showcase study' home workhouse was built at 88 East Street, Clifton in the Toowoomba region as a key output of the creative suburb research.

\section{CREATIVE REFLECTIVE PRACTICE}

In essence, the creative suburb research involved two interconnecting and flowing research 'streams': (1) creative practice evidenced in two, related, year long projects (action research) and (2) reflective practice evidenced in a related exegesis (reflective research). A significant amount of 'fishing' has been done in both these streams, springing from the work of Schön [18], who coined the term 'the reflective practitioner', through to Ulrich [19] who goes to the extent of claiming that 'no theoretical scheme of methodology choice can comprehensively 
supersede reflective practice' [19]. A crucial facet of the creative suburb research was to develop confidence 'about the parameters of reflection and the building blocks which make it what it is' [20], which as Ixer [20] also says 'are needed, and until such time (as these have been developed) there is no such thing as reflection' [20].

Writing an effective and structured reflective journal (e.g. Johns [21]) is one highly recommended reflective research technique, and in the author's case, the (almost) daily discipline involved in producing a series of reflective journals emerged as not only a key to reflective practice, but essential to creative practice.

Indeed, the reflective journals are where the reflective and creative streams circled, cycled, collected, and then settled; the confluence and coincidence of the creative and reflective suggesting there is a theory and methodology of creative reflective practice involving a blend of concepts typically referred to as 'reflective practice' and 'action research'.

Leading reflective practitioner and advocate Johns [21] cites Gibbs's [22] process to be utilised in and structure journal entries, that a 'reflective cycle' involves: description (of what happened); feelings (what was thought and felt); evaluation (what was good and bad about the experience); analysis (what sense can be made of the situation); conclusion (what else could have been done); action plan (if the situation arose again, what to do?), which returns to description, and so on [21].

Similarly, McMahon [23] identifies the major concordance between Kolb's learning 'cycle' and the action research 'spiral', in that they both emphasise the importance of reflection on action and experience. In both models, the reflection is intended to be transformative. In the case of the learning cycle, this transformation can be mainly internal (i.e. concerned with knowledge or attitude - 'inside'), whereas, in the case of the action research spiral, there is always an explicit strategic attempt to improve practice (which is observable - on the 'outside'). In relation to the creative suburb, the research is not only performative (e.g. Haseman [5]), it tended to be transformative.

McMahon [23] says that strategic action is a deliberate and planned attempt to solve a particular problem or set of problems using a coherent, systematic, and rigorous method. McMahon reinforces this notion in saying that action research, by definition, always involves such strategic action, but, by contrast it is not integral to reflective practice. Reflective practice can lead to strategic action, but this is not inevitable. Reflective practice can be a useful precursor to action research. It is not identical to it [23]. McMahon concludes: 'reflective practice can be used to identify problems; action research can seek to provide solutions' [23]. The 'reflective pond' emerged as a metaphor driving key outputs of this research, including expressions of reflection-before-action, reflection-on-action, and significantly in a design development context, reflection-in-action.

As Rolfe [24] describes, reflection-in-action is a reflection which takes place in the practice setting rather than retrospectively; it is a situation where each of the phases of the reflective cycle (e.g. Gibbs [22]) is compressed into a live, real-time practice setting so quickly and seamlessly, as to become a single process. This is the author's experience of almost daily entries to a reflective journal, a repository of reflection before, on, and most significantly in, design practice - whether it is design being done by one's self or collaboratively in a workshop. This creative-plus-reflective process resonates as a form of real-time problem solving, which Schön refers to as 'on-the-spot experimenting' [24]. This process might be referred to as an 'inside the moment' blend of creative and reflective practice, what Schinke et al. [25] refer to as 'reflexive practice' involving 'reflex actions' which may be involuntary, instantaneous and unexpected; a 'reflexive praxis' perhaps, informed and inspired by Gray [26] who writes: 
I very much like the idea of 'encountering' theory. It suggests that, as a result of active exploration, we might come upon or discover unexpectedly relevant ideas. It is dynamic, moving. It suggests an event, possibly a serendipitous meeting, an experience that might surprise us or challenge us. On a darker note an encounter also suggests a meeting in battle or contest. We can evade or engage. Encounters can create tensions, and challenges can provoke creative responses.

(Gray [26])

Schinke et al. [25] note that reflexivity is a nuanced form of reflective practice based upon an emerging innovation in qualitative methodology whereby researchers situate their own personal identities and biases to explore surprises and un-doings in the research process (i.e. unexpected turns in the research process).

Thankfully, the creative suburb research involved more surprises than un-doings: the process was a continual flow of serendipitous connections and synchronistic collections forming, in particular, new patterns of design language which then informed the detailed design of the home workhouses and their sitting on a lot, in a block, on a street, near a park, in a neighbourhood, in the suburb.

Paramount in the concept of a creative reflective practice model/approach intuited during this research is that it gave new meaning and an unanticipated depth of support to the use of a range of design tools and techniques, which the author has developed over a life time, to support not only professional practice, but as it turned out, personal life. These tools and techniques have been derived from learnings that go back to 'doing' art at high school in the late 1970s, study in urban design in the late 1980s, and a concerted effort throughout an honour year 2010 to consider the use of phenomenology in urban planning design and development. In recent years, in particular relation to the reflective stream of the creative suburb research, this led to the discovery of the leading and comprehensive work of Embree [27] who posits that phenomenology is quintessentially 'reflective analysis'.

Embree [27] states that 'a phenomenological approach chiefly requires two things: (1) adopting a suitable attitude, which is fundamentally reflective and theoretical, and (2) engaging in observation and what can be called analysis' [27], an assertion which echoes Ulrich [19] and Ixer [20].

The process of preparing the building and urban designs thus drew on works in phenomenology (as philosophy/metaphysics, epistemology, ontology, theory, methodology, and methods): notably embedding the prolific works in the development of a 'Poetic Pattern Language' by Alexander [28-30].

\section{METRICS, MECHANICS AND METAPHOR}

The new building and urban design patterns generated through the phenomenology-inspired creative-reflective research process coalesced into three broad categories: (1) metrics (detailed measured drawings and mathematical analysis); (2) mechanics (detailed expressions of planning and process); and (3) metaphor (poetic/artistic expressions and resemblances).

All three creative-reflective approaches are required in design, but it is in the metaphors where the inspiration (to design, to study, to reflect) were and are sustained. Schön [18] acknowledges metaphor as being integral to architecture and design, and Casakin [31] argues that it is essential in problem-solving tasks, where reasoning by metaphors has a significant influence in the development of innovative ideas [31]. The realisations of this research have thus been revealed through both creation and reflection, on information or data revealed through the following forms of creative reflective research/practice: 
Self-oriented creative +reflective research/practice: This includes journal entries and reflection on journal entries - in the design field this includes 'on-the-spot experimenting' and in my case use of the 'metrics pages' (also 'mathematical pages') and 'mechanics pages' (inspired by Alexander [30]), 'metaphormal pages' (inspired by Schön [18]), and at times, 'morning pages' (inspired by Cameron [32]).

Guided/other-oriented creative+reflective research/practice: This includes creative-reflective research with others (inspired by Johns [21]) - such as supervisory team meetings via review, analysis and critique of progress via text, plans, images, diagrams; and collaborative design - such as generative workshops and product design-related mini-focus group work.

Results-oriented creative+reflective research/practice: This includes transcripts + content analysis - including text analysis, theme distillation and preliminary building and urban design 'patterns' - of interviews and design workshop outputs (inspired by Webster and Mertova [33]), as well as analysis of data revealed through ongoing contextual and literature review.

The creative suburbia research involved over 170 interviews of suburban-based CIWs stretching from Melbourne, Victoria to Redcliffe, Queensland. The creative suburb research checked in on the emergent outcomes of the creative suburbia research through 13 interview sessions with CIWs and property developers (e.g. designers and builders of the Soho) operating in southeast Queensland including one household of CIWs in Toowoomba.

The interviews and a series of resultant design workshops suggested three possible building typologies (and topologies on the lot/site): 'studio' (this includes a small, typically one room self-contained apartment, as well as a space for arts, crafts, etc. - could be anywhere on the lot); 'shop' (e.g. a gallery, office, or retail outlet which is typically at the front of the lot and close to the street); and 'workshop' (for noisy or dirty work, e.g. music recording, metal sculpture, which might be typically at the rear of a lot and accessed via a rear lane say to make it easy for the roadie).

The spatial requirements addressed in all of the interviews and brought to a head at the design workshops determined that the minimum internal spatial area for these working spaces should be $3.6 \mathrm{~m} ¥ 3.6 \mathrm{~m}$ with ceiling height preferably over $3.0 \mathrm{~m}$. These dimensions reflect a very clear consensus on some key design principles/requirements: CIWs want light and air, at least a courtyard outlook, a veranda, and if at all possible a garden; and they also want to be able to walk or cycle around a neighbourhood and be close to parks, shops, and other services. The latter are factors which flow through the creative city literature [6, 7, 34]; while the former figure large in the creative suburb literature $[35,36]$.

The ability to have choice in spatial use via flexible open spaces within the building or in a separate building within the lot became fundamental considerations in the building designs. Initially, it was considered that the adoption of 'shop', 'workshop' and 'studio' would sufficiently express this flexibility in that buildings, respectively, available for 'retail', 'service/ industry', and 'commercial' use could be suitable and very attractive to other home-based business operators or hobbyists as they could be for CIWs. Eventually, however, the call to flexibility in response to the 'flex' and 'flux' of life and work for CI homeworkers determined that a broader categorisation of spaces and places be generated - to some extent an ambiguity of spatial use and definition is demanded - to open up consideration for the immense variety of creative industries work which could be undertaken. The following terms thus became a necessary lexicon, a poetic pattern language (see Alexander [30]) in particular focusing the detailed interior and exterior design of a 'showcase study' 'home workhouse' for 88 East Street, Clifton, in the Toowoomba region. 
Residential space: A living and/or dwelling space 'recreational' homework

Exhibition space: A display space for installations, artworks (e.g. gallery), projections, and/ or functions as well as a place where wares/goods are offered for retail/sale to customers (shop/store) 'retail' homework

Performance space: A space for presentations, concerts, recitals, and shows including music, aerial circus, lectures, and workshops in the sense of a space for a group of people working on a creative project, discussing a topic, or studying a subject - includes space for an audience as in a theatre (which may also overlap with showing of a movie or other projection as part of an exhibition)

'expressive' homework

Storage space: A space to store, stock, and/or hold something for safekeeping including a 'warehouse', as against a 'store' where stuff is stored/kept for sale

'contained' homework

Workshop space: A space where wo/manual work is done, especially manufacturing or repairing and/or sculpting - can include a 'garage' in the sense of motorcycle maintenance or simply storing a precious motor vehicle or two (note overlap with storage space)

'service-industrial' homework

Writer's space: A space where any type of written work is done, including an office, study, library, or retreat - typically a space or room, a curio or bureau - which can include for the creative writer a plethora of 'ritualistic paraphernalia', but at the very least; 'a chair, a table, silence, and a little awe' [37]

'commercial' homework

It was further intuited that the preferred location and likely expression of each of the above uses and spaces led naturally to the coupling of residential + writer's, workshop + storage, and performance + exhibition spaces, which in turn meant that each building design in the creative suburb series would need to include at least one each of these combinations.

\section{BLUES BAR @ 88 EAST STREET, CLIFTON}

'12 Blues Bar' (Fig. 3) is the smallest in the designs developed throughout the creative suburb research. On face value, the design hardly seems creative and is somewhat underwhelming. It nonetheless includes - from front to back - the performance + exhibition, workshop + storage, and writer's + residential spaces within the minimum $3.6 ¥ 3.6 \mathrm{~m}$ internal dimensions of the main building modules. Figures $4-6$ show three variations of potential use of the front flexispace. The design also includes the quintessentially Queensland (and Australian), liminal, if not heterotopian space which Drew [38] says is the "spatial catalyst which puts Australians in touch with their country' (Figs 7 and 8) - a 'waiting room' as described by one of the interviewees built up to the front boundary of the lot. The 'timber and tin' expression and pitched roof reflect the buildings in East Street; the towns original blacksmith's shop on the property to the west of 88EaSt is in particular similarly expressed. The front and back flexi-spaces in the building are separated by a hallway providing access to a fully wheelchair accessible bathroom. The back flexi-space is shown set up as a writer's + residential space (Fig. 9) complete with bar. 


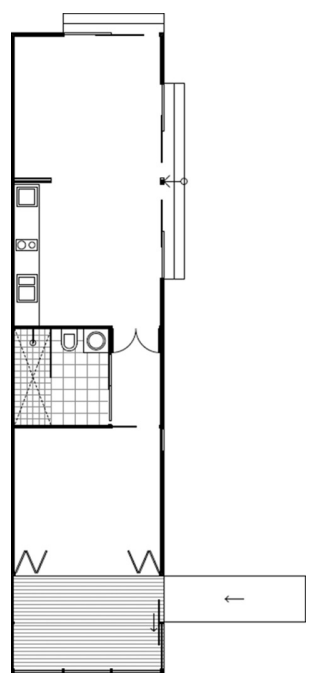

Figure 3: Front elevation and plan of '12 Blues Bar' - showcase study home workhouse built at 88 East Street, Clifton.

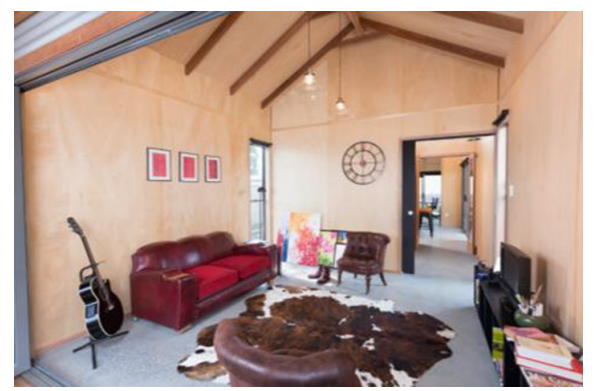

Figure 4: Writer's + residential space (image (C) Cian Sanders).

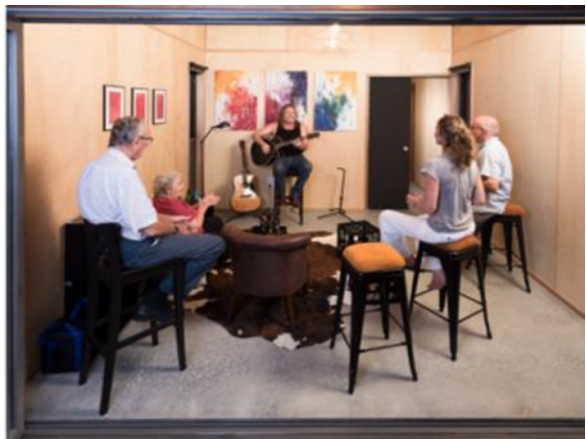

Figure 5: Performance + exhibition space (image (C) Cian Sanders). 


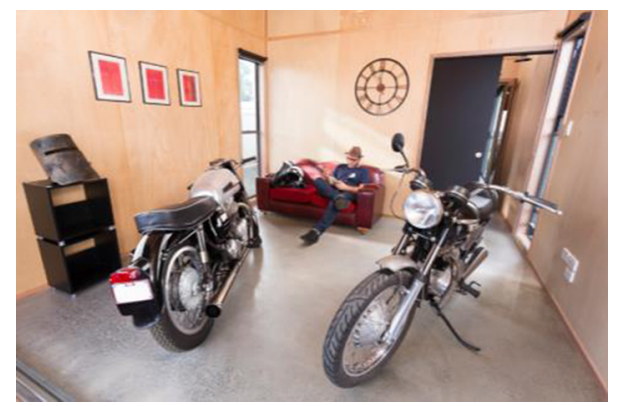

Figure 6: Workshop + storage space (image (C Cian Sanders)

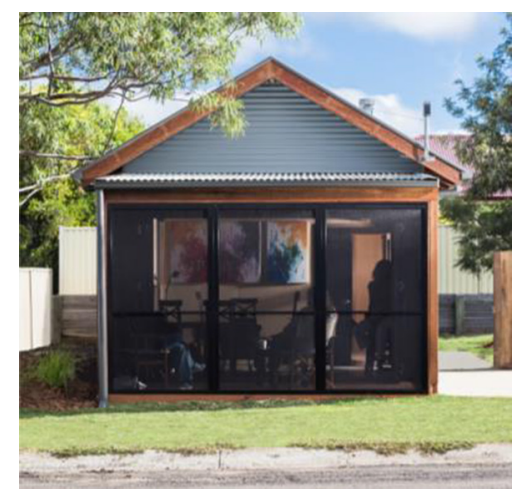

Figure 7: Front view of '12 Blues Bar' built at 88 East Street, Clifton (image ( $)$ Cian Sanders).

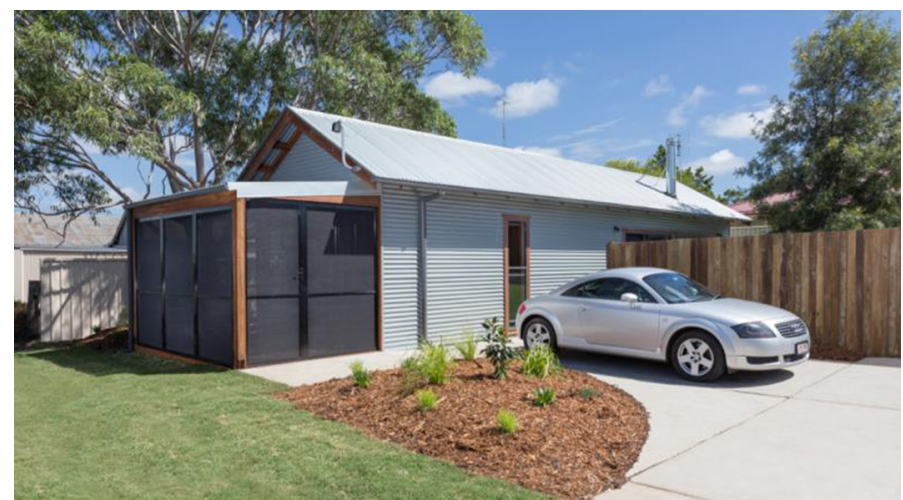

Figure 8: Oblique view of '12 Blues Bar' built at 88 East Street, Clifton (image (C) Cian Sanders). 


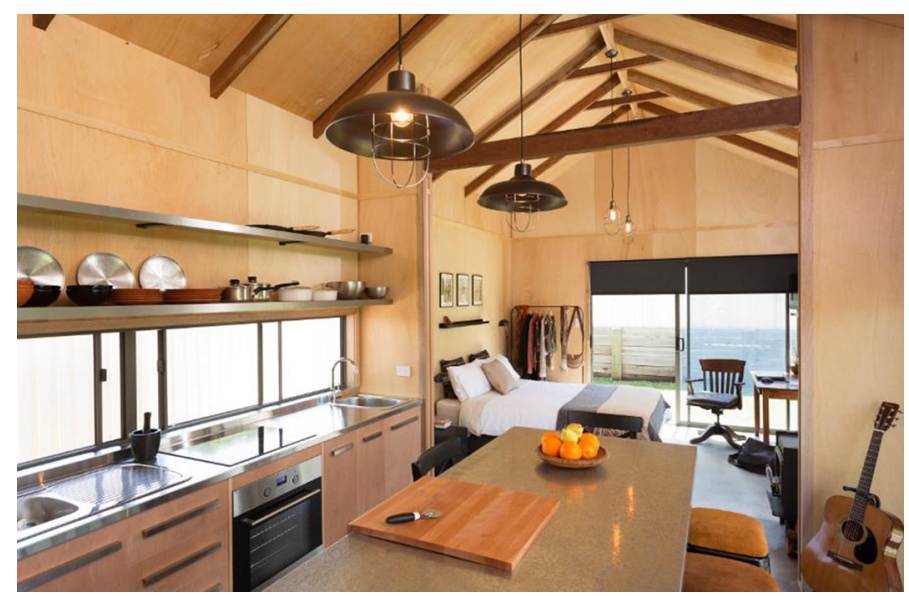

Figure 9: Writer's + residential space in '12 Blues Bar' built at 88 East Street, Clifton (image (C) Cian Sanders).

\section{CONCLUSION}

Creative reflective research has emerged as a methodology befitting the blend of methods used in the creative suburb research, including design, development, and delivery of the showcase study home workhouse at $88 \mathrm{EaSt}$; writing and producing a book expressing the research findings in voxpopoli; and a research exegesis. In particular, creative reflective practice - 'refluxive praxi' - is proffered here as another nuanced methodology having the possibility to progress the professional practice of reflection, which Ulrich [19] suggests is the methodology of choice in research.

Critical reflections on the creative suburbia research set the foundation for the creative suburb research. Reflective practice was used as a research method alongside traditional methods such as semi-structured interviews, design workshops, and geospatial analysis of building and urban design options generated. Analysis of the content of interviews undertaken confirmed the creative suburbia research revelations and helped establish a set of poetic and other parameters and patterns, which flowed through the building designs.

The continuing contextual review provided the basis of a suburban design approach, which meets current best development industry practice and supports emerging and progressive planning and design regulations, particularly those evident in the Toowoomba regional planning scheme. The ongoing literature review continually challenged yet guided the direction of the research, notably in contrast to - but at the same time acknowledging the significance of - the works of highly influential creative industries and creative place thinkers such as Florida [6, 34] and Landry [7]. The Australian presence in the vernacular creativity research (e.g. Gibson et al. [39]) and the fact that the creative suburbia research was driven by Queenslanders (e.g. Collis and Felton [35]), proved an inspiration to innovate in a Queensland greenfield suburban context.

Early indications - via assessment of the showcase study home workhouse built at 88EaSt - are that the building designs generated during the creative suburb research programme could easily compete with and be a more attractive, robust, and flexible proposition than mainstream, domestic, and traditional suburban housing designs. The home workhouse designs also do more than tilt at taking away Australia's dubious title of having the fattest 
houses in the world; in many ways, they reflect a burgeoning micro-property movement, which nonetheless respect those with mobility and other physical challenges, who should find it easy to manoeuvre in what are small houses by current Australian trends.

In this regard, the percentage and number of CIWs as against other professions and workers is small, if not insignificant. This is an issue when the research is focused entirely on CIWs who make up such a small proportion of the working population. The focus of the creative suburb is, however, suggesting a universal need to change the way we think about planning and designing suburban houses. The primary point here is that the 'flex' and 'flux' of life is not restricted to the CIW. Flexibility is the new sustainability.

The relevance of this research may therefore be for not only the CIW (CIWs do not have a monopoly on creativity), but for all productive and creative people who may want a choice in how they live and work within their home; what's to say that the accountant may love motorcycles? In essence, a performance exhibition space is a 'shop' by any other name or it could be an office for any business requiring office space, a workshop storage space may be great for the motorcycle enthusiast, carpenter, or for compulsive hoarders or collectors, a writer's residential space could be the home office for anyone involved in running a business and having to deal with the administrative side of things after hours and at home.

This brings the creative suburb into a far more expansive area of possible influence and relevance. Whilst the building at $88 \mathrm{EaSt}$ has been done for CIWs, the spaces which could be created within them are suitable for anyone wanting to undertake a micro-small business from home. As in all the building designs produced through the creative suburb research, 88EaSt has a fall-back or -forward position, in that the building can be simply and solely used as a residence. It is this flip-flop opportunity to readily adapt the building for a variety of uses, which is the probable penultimate advantage. Indeed, it is the spatial ambiguity inherited in the design of $88 \mathrm{EaSt}$, which is giving rise to further creative reflection; the showcase study home workhouse virtually forcing consideration of what range of uses might be made of the spaces available. The next phase of research is to capture and critically evaluate what potential and beginning users report on their experience of $88 \mathrm{EaSt}$, a continuing creative reflective building produced as a result of creative reflective research (see also Holz [40]). Further research could also address whether, where, and under what conditions the home workhouse could be developed in 'creative villages' both within city centres and well beyond city suburban limits: 'suburbs with soul' and 'hamlets with heart'.

\section{REFERENCES}

[1] Reynolds, M., Reflective practice: origins and interpretations. Action Learning: Research and Practice, 8(1), pp. 5-13, 2011. doi: http://dx.doi.org/10.1080/14767333.20 11.549321

[2] Chiu, L.F., Critical reflection: more than nuts and bolts. Action Research, 4(2), pp. 183-203, 2006. doi: http://dx.doi.org/10.1177/1476750306063991

[3] Stock, C.F., Approaches to acquiring 'doctorateness' in the creative industries: an Australian perspective, Pre-Conference Proceedings, eds. L. Justice \& K. Friedman, Hong Kong Polytechnic University: Hong Kong, 2011.

[4] Allpress, B. \& Barnacle, R. Projecting the PhD: architectural design research by and through projects, Changing Practices of Doctoral Education, eds. D. Boud \& A. Lee, Routledge: Oxford, 2009.

[5] Haseman, B., A manifesto for performative research, Media International Australia Incorporating Culture and Policy, 118, pp. 98-106, 2006. 
[6] Florida, R., The Rise of the Creative Class: And How It's Transforming Work, Leisure, Community and Everyday Life, Basic Books: New York, 2002.

[7] Landry, C., The Creative City: A Tool Kit for Urban Innovators, Earthscan Publications Ltd: UK, 2008.

[8] Evans, G.L., From cultural quarters to creative clusters - creative spaces in the newcity economy, available at http://www.citiesinstitute.org/londonmet/fms/MRSite/Research/ cities/079-cultural_quarters_and_urban_regeneration-090722-evans.pdf, 2009.

[9] Higgs, P., Cunningham, S. \& Pagan, J., Australia's Creative Economy: Definitions of the Segments and Sectors, ARC Centre of Excellence for Creative Industries \& Innovation (CCI): Brisbane, 2007, available at http://eprints.qut.edu.au/archive/0008242/.

[10] Heidegger, M., Poetry Language Thought, New Harper and Row: New York, pp. 145-146, 1975.

[11] Felton, E. \& Collis, C., Creativity and the Australian suburbs: the appeal of suburban localities for the creative industries workforce. Journal of Australian Studies, 36(2), pp. 180-181, 2012. doi: http://dx.doi.org/10.1080/14443058.2012.676560

[12] Edensor, T., Leslie, D., Millington, S. \& Rantisi, N.M. (eds.), Spaces of Vernacular Creativity: Rethinking the Cultural Economy, Routledge: Abingdon, Oxon, 2009.

[13] Duany, A., Speck, J. \& Lydon, M., The Smart Growth Manual, McGraw Hill, 2010.

[14] Dolan, T., Live-Work Planning and Design: Zero Commute Housing, New Jersey, NY: John Wiley and Sons, 2012.

[15] Holliss, F., Home is where the work is: the case for an urban design revolution, London Metropolitan University, available at http://theconversation.com/home-is-where-thework-is-the-case-for-an-urban-design-revolution-8147 20141213:10:14am, 2012.

[16] DSDIP, Queensland Planning Provisions, Queensland Department of State Development Infrastructure and Planning, 2011.

[17] SPA, Sustainable Planning Act 2009, available at https://www.legislation.qld.gov.au/ LEGISLTN/CURRENT/S/SustPlanA09.pdf

[18] Schön, D.A., The Reflective Practitioner: How Professionals Think in Action, Basic Books: New York, 1983.

[19] Ulrich, W., Rethinking critically reflective research practice: beyond Popper's critical rationalism. Journal of Research Practice, 2(2), article P1, 2006.

[20] Ixer, G., There's no such thing as reflection: ten years on. The Journal of Practice Teaching and Learning, 10(1), p. 75, 199, 2010.

[21] Johns, C., Being and Becoming a Reflective Practitioner, Blackwell Publishing: London, 2002.

[22] Gibbs, G., Learning by Doing: A Guide to Teaching and Learning Methods, Further Education Unit, Oxford Polytechnic: Oxford, 1988.

[23] McMahon, T., Is reflective practice synonymous with action research? Educational Action Research, 7(1), 1999. doi: http://dx.doi.org/10.1080/09650799900200080

[24] Rolfe, G., Beyond expertise: theory, practice and the reflexive practitioner. Journal of Clinical Nursing, 6, pp. 93-97, 1997. doi: http://dx.doi.org/10.1111/j.1365-2702.1997. tb00290.x

[25] Schinke, R.J., McGannon, K.R., Parham, W.D. \& Lane, A.M., Toward Cultural Praxis and Cultural Sensitivity: Strategies for Self-Reflexive Sport Psychology Practice, Taylor \& Francis: Quest, 2012. doi: http://dx.doi.org/10.1080/00336297.2012.653264

[26] Gray, C., From the ground up: encountering theory in the process of practice-led doctoral research, Internal paper, Faculty of Design and Technology, Scotland, 2007. 
[27] Embree, L., Reflective Analysis - Pathways to Phenomenology 1, Zeta Books, Florida Atlantic University: Boca Raton, FL, 2006.

[28] Alexander, C., A Pattern Language, Oxford University Press: New York, NY, 1977.

[29] Alexander, C., The Nature of Order: An Essay on the Art of Building and the Nature of the Universe, The Centre for Environmental Design Research: Berkeley, CA, 2002.

[30] Alexander, C., A Poetic Pattern Language, available at http://www.livingneighborhoods.org/actions/poeticpl.htm, 2010.

[31] Casakin, H.P., Metaphors in design problem solving: implications for creativity. International Journal of Design, 2007.

[32] Cameron, J., The Artist's Way, William Morrow: New York, 1995.

[33] Webster, L. \& Mertova, P., Using Narrative Inquiry as a Research Method, Routledge: New York, 2007.

[34] Florida, R., The Rise of the Creative Class Revisited, Basic Books: New York, 2012.

[35] Collis, C. \& Felton, E., Creativity and the Australian suburbs: the appeal of suburban localities for the creative industries workforce. Journal of Australian Studies, 36(2), pp. 177-190, 2012. doi: http://dx.doi.org/10.1080/14443058.2012.676560

[36] Felton, E., Working in the Australian suburbs: creative industries workers' adaptation of traditional work spaces. City Culture and Society, 2013.

[37] Maisel, E., The Writer's Space, Adams Media: Avon, MA, p. 5, 2008.

[38] Drew, P., Veranda: Embracing Place, Angus \& Robertson: Australia, 1992.

[39] Gibson, C., Luckman, S. \& Willoughby-Smith, J., Creativity without borders? Rethinking remoteness and proximity. Australian Geographer, 41(1), pp. 25-38, 2010. doi: http://dx.doi.org/10.1080/00049180903535543

[40] Holz, M., The creative suburb: building and urban designs for suburban innovators. WIT Transactions on Ecology and the Environment, 193, 2015. 